\title{
Understanding the Transition from Informal to Formal Business: A Conceptual Framework
}

\author{
Professor Dennis Yao Dzansi \\ Ms Rolline Tasssin-Njike
}

Department of Business Support Studies; Faculty of Management Sciences Central University of Technology, FS; Bloemfontein, South Africa

ddzansi@cut.ac.za

\section{Doi:10.5901/mjss.2014.v5n20p664}

\begin{abstract}
Although there may be incentives for a businesses to remain informal, formalisation comes with many advantages. However, as some 'graduated' businesses will attest to, the process of formalisation can be very challenging. In order to make the formalisation journey less challenging, there is need for informal businesses to fully comprehend what it takes to transit from an informal to a formal business. The purpose of this paper was to provide a conceptual framework for studying and comprehending the transition of a business from the informal to the formal sector. The ultimate aim is to assist owners and managers of informal businesses to transit into the formal sector so as to reap the benefits associated with formalisation while allowing society in general to also benefit from increased job creation, tax contributions and social responsibility contributions and so on that result from formalisation of a business. In this paper, the researchers conducted a desk research by reviewing the literature to understand the informal to formal business transition process. This led to the identification of variables incorporated into the conceptual framework. While there can be no one-size-fits-all framework to address a research problem, academic, policy makers, as well as students will find the framework useful in their various endeavours.
\end{abstract}

Keywords: informal business; formal sector; 'graduated businesses'; South Africa.

\section{Introduction}

The purpose of this paper is to provide a conceptual framework for studying and comprehending the transition of a business from the informal to the formal sector. The ultimate aim is to assist owners and managers of informal businesses to reap the benefits associated with formal businesses while allowing society in general to also benefit from increased job creation, tax contributions and social responsibility contributions and so on that formalisation entails.

The paper begins with presentation of the problem and its setting followed by the objective. Thereafter the methodology followed is provided with justification thereof. This is followed by a summary of the related literature reviewed. This includes: locating informal businesses in the wider context of the SMME sector; making the case for formalisation; discussion of the importance of informal businesses and for that matter the contribution of SMMEs in socioeconomic development; as well as presenting the underlying theoretical framework. After this the conceptual framework is presented and discussed. The paper ends with a conclusion.

\section{The Problem and Its Setting}

Conversation with some informal business people in South Africa suggest that although many informal businesses would like to formalise, they perceive the process as cumbersome. In other words, there are challenges to overcome when transiting from informal business to a formal one. Some owners also pointed out that formalising will expose them to paying taxes so they would rather remain informal. Put differently, informal businesses are motivated to remain informal in order to avoid paying tax. The information from the informal conversations although insightful, remain speculative. They need to be rigorously tested in a scientific manner in order to fully comprehend what it really takes an informal business to successfully transit to the formal sector in South Africa. The problem is that without a systematic study, no one will ever know for sure what motives drive informal businesses to seek formalisation - that is, what opportunities most attracted the businesses to formalise; the challenges they have to deal with; the personal characteristics that owners rely on most in dealing with the challenges of transition; and what strategies can be put in place to reduce if not eliminate the challenges 
of transition from informal to formal business. In addition it will be extremely difficult to identify ways of overcoming these challenges.

In this study, the researchers argue that to conduct research on a specific issue requires a guiding framework. The need for a guiding framework is to focus research. To the best of our knowledge, no framework exist to guide research into the transition process from the informal to the formal sector in the South African context.

\section{Objective of the Study}

As alluded to in the opening paragraph of this paper, the singular objective of this study is to provide a conceptual framework for researching hence understanding what it takes an informal business to 'graduate' into a formal business in the South African context with possible extension to the same process in other countries. The next section details the methodology applied in arriving at the framework.

\section{Methodology}

The position taken in this research is that "people's knowledge, views, understandings, interpretations, experiences, and interactions constitute meaningful properties of social reality" (Mason, 2007). That is, social reality is best captured through the views, understandings, interpretations, and experiences of actors themselves. Thus, to understand the informal to formal business transition process, it is best to see it through the lenses of the 'graduated' owners. Consistent with this philosophical position, the interpretivist approach was adopted. The interpretivist philosophical position implied a qualitative research design - the collection of qualitative data and data analysis that does not involve numerical methods. Specifically, desk research was conducted by reviewing the literature leading to identification of variables incorporated into the conceptual framework. The next section provides a summary of the literature review.

\section{Literature Review}

Informal businesses also collectively known as the informal sector form an important integral segment of what is globally known as the small, medium, and micro enterprise (SMMEs) or the SMME sector. Informal businesses and for that matter SMMEs have of late been featuring prominently in policy and research agenda in in all countries presumably because of the important role of the SMME sector as a whole in socio economic development of countries, regions and localities (Dzansi and Pretorius, 2009). Therefore, to understand what it takes for informal businesses to transit into the formal sector first requires exposition of the composition of the SMME sector where they are located.

\subsection{What Constitutes SMMEs?}

It is important to point out that there is no single universally acceptable definition for SMMEs since it differ from one country to another and also because even within a country, differences still exist (Dzansi 2004; Awan, Goodson and Watfa, 1998). For example, the Organisation for Economic Co-operation and Development (OECD) (2005) simply views SMMEs as firms with fewer than 500 employees. However, in the South African context, the overriding definition is the one contained in the National Small Business Act, No. 102 of 1996. According to this Act, a small business is: "A separate and distinct business entity, including co-operative enterprises and non-governmental organisations, managed by one owner or more which, including its branches or subsidiaries, if any, is predominantly carried on in any sector or sub-sector of the economy and which can be classified as micro-, a very small, a small or a medium enterprise". The Act goes on to classify the businesses as micro, very small, small, and medium according to a mix of criteria such as sector, turnover, asset base, and number of employees.

To surmise, the National Small Business Act, No. 102 of 1996 provides the following classifications for SMMEs in South Africa:

- Businesses with fewer than 200 employees, with an annual turnover of less than 40 million rands and gross asset value of less than 18 million rands as medium enterprises.

- Businesses with less than 50 employees, with less than 25 million rands in total annual turnover and less than 4 million rands gross asset value as small enterprises.

- Businesses belonging to the 'very small' category are those with less than 10 employees, with less than 4 million rands annual turnover and less than 1.8 million rands gross asset value. 
- Lastly, businesses with less than 5 employees, with less than 0.15 million rands annual turnover and less than 0.10 million rands asset value are regarded as micro.

For the purpose of this study, SMMEs are defined in accordance with the National Small Business Amendment Act, No. 29 of 2004. This means that an SMME in this study refers to "a separate and distinct entity including cooperative enterprises and non-governmental organizations managed by one owner or more, including its branches or subsidiaries predominantly carried out in any sector or sub-sector of the economy mentioned in the schedule of size standards" (National Small Business Amendment Act, No. 29 of 2004). To locate informal business in the SMME sector, it is important to consider the small business classification in much detail. This detail is provided in Table 1 below.

Table 1: Schedules of SMMEs in South Africa

\begin{tabular}{|c|c|c|c|c|}
\hline Sector/sub-sector & Size of Class & Total number of ful-ime employees & Annual turnover & Total gross asset value \\
\hline \multirow[t]{4}{*}{ Agriculture } & Medium & 100 & R5m & R5m \\
\hline & Small & 50 & $R 3 \mathrm{~m}$ & R3m \\
\hline & Very small & 10 & Ro.50m & Ro.50m \\
\hline & Micro & 5 & $R 02 \mathrm{~m}$ & $\mathrm{R} 0.10 \mathrm{~m}$ \\
\hline \multirow{4}{*}{$\begin{array}{l}\text { Mining and } \\
\text { Quarrying }\end{array}$} & Medium & 200 & R39m & $\mathrm{R} 23 \mathrm{~m}$ \\
\hline & Small & 50 & Riom & Rism \\
\hline & Very small & 20 & R4m & R2m \\
\hline & Macro & 5 & $\mathrm{RO} 20 \mathrm{~m}$ & Ro. $10 \mathrm{~m}$ \\
\hline \multirow[t]{4}{*}{ Manufacturng } & Medium & 200 & R51m & R19m \\
\hline & Small & 50 & R13m & RSm \\
\hline & Very small & 20 & R5m & $R 2 \mathrm{~m}$ \\
\hline & Micro & 5 & Fo. $20 \mathrm{~m}$ & $80.10 \mathrm{~m}$ \\
\hline \multirow{4}{*}{$\begin{array}{l}\text { Electricily gas } \\
\text { And water }\end{array}$} & Medium & 200 & RSim & $\mathrm{R} 19 \mathrm{~m}$ \\
\hline & Small & 50 & R13m & R5m \\
\hline & Very small & 20 & $\mathrm{R} 5.10 \mathrm{~m}$ & R1.9m \\
\hline & Micro & 5 & Ro $20 \mathrm{~m}$ & $\mathrm{R} 0.10 \mathrm{~m}$ \\
\hline \multirow[t]{4}{*}{ Construction } & Medium & 200 & RR26m & $\mathrm{R} 5 \mathrm{~m}$ \\
\hline & Small & 50 & $\mathrm{R} 6 \mathrm{~m}$ & Rim \\
\hline & Very small & 20 & $\mathrm{R} 3 \mathrm{~m}$ & R0.50m \\
\hline & Micro & 5 & $\mathrm{R} 0.20 \mathrm{~m}$ & R0.10m \\
\hline \multirow{4}{*}{$\begin{array}{l}\text { Retail and motor } \\
\text { Trade and Repair } \\
\text { services }\end{array}$} & Medium & 200 & $\mathrm{R} 39 \mathrm{~m}$ & R6m \\
\hline & Small & 50 & R19m & $R 3 m$ \\
\hline & Very small & 20 & RAm & Ro.60m \\
\hline & Macro & 5 & $\mathrm{R} 0.20 \mathrm{~m}$ & $R 0.10 \mathrm{~m}$ \\
\hline \multirow{4}{*}{$\begin{array}{l}\text { Wholesale Commercial } \\
\text { Agents \& alled Services }\end{array}$} & Medium & 200 & R5s4m & R10m \\
\hline & Small & 50 & R32m & RSm \\
\hline & Very small & 20 & Rím & 700.6m \\
\hline & Micro & 5 & R0.20m & R0.10m \\
\hline \multirow{4}{*}{$\begin{array}{l}\text { Catering. } \\
\text { Accommodation } \\
\text { And other Trade }\end{array}$} & Medium & 200 & $R 3 m$ & $\mathrm{~F} 3 \mathrm{~m}$ \\
\hline & Small & 50 & Rim & Rim \\
\hline & Very small & 20 & R19 & R19m \\
\hline & Micro & 5 & R0.10 & Ro.10m \\
\hline \multirow{4}{*}{$\begin{array}{l}\text { Transport Storage } \\
\text { and Communications }\end{array}$} & Medium & 200 & R26m & Finm \\
\hline & Small & 50 & $\mathrm{R} 13 \mathrm{~m}$ & $R 3 m$ \\
\hline & Very small & 20 & $R 3 \mathrm{~m}$ & Fo. $60 \mathrm{~m}$ \\
\hline & Micro & 5 & $\mathrm{R} 0.20 \mathrm{~m}$ & Fo. $10 \mathrm{~m}$ \\
\hline \multirow{4}{*}{$\begin{array}{l}\text { Finance and Business } \\
\text { services }\end{array}$} & Medium & 200 & R26m & R5sm \\
\hline & Small & 50 & R13m & $R 3 m$ \\
\hline & Very small & 20 & $R 3 m$ & R0.50m \\
\hline & Micro & 5 & R0.20m & Fo. $10 \mathrm{~m}$ \\
\hline \multirow{4}{*}{$\begin{array}{l}\text { Community social and } \\
\text { Personal Services }\end{array}$} & Medium & 200 & R13m & Rism \\
\hline & Small & 50 & R6m & $R 3 m$ \\
\hline & Very small & 20 & $\mathrm{R} 1 \mathrm{~m}$ & $\mathrm{R} 0.6 \mathrm{~m}$ \\
\hline & Micro & 5 & $\mathrm{R} 020 \mathrm{~m}$ & R0.10m \\
\hline
\end{tabular}

Source: National Small Business Amendment Act, No. 29 of 2004

From Table 1, it is clear that the most likely nature of informal business will be in the micro business category where there are 5 or fewer employees and where gross turnout and asset values are minimal.

\subsection{Informal Businesses}

Like SMMEs, several definitions have been coined for the informal sector (the collection of informal businesses). The social anthropologist, Keith Hart, first coined the term informal sector in the 1970s and used the term in the developing world context to describe a part of the urban labour force, which works outside the formal labour market. Hart (1973) described the informal sector as a traditional urban economy with a low level of productivity and informal income opportunities whether in primary, secondary or tertiary economic activities. For Hart (1973), the informal sector is almost synonymous to all categories of (small) self-employed individuals. Amongst the many other definitions of the informal sector are: "unorganised and mostly legal but unregistered economic activities that are individually or family owned and 
use simple, labour intensive technology" (Barker, 2003); "unregistered business, run from homes, street pavements or other informal arrangements" (Statistics South Africa [STATSA], 2003); and "enterprises that are not legally regulated by the institutions of society in a legal and social environment in which similar activities are regulated" (Portes and Haller, 2005). For the purpose of this study, Portes and Haller's (2005) definition is adopted since it appears to capture the essence of most definitions. The adopted definition of informal business makes it much easier to understand why such businesses would want to formalise their operations.

The micro feature of informal businesses enables them to require low start-up capital hence they can be seen as the easiest entry point for absorbing socio-economically underprivileged people in any country who lack education hence skills to gain formal employment; or the financial resources to start it big or formal. However, the same micro nature exposes informal businesses to the disadvantages of economies of small scale. Thus, it is reasonable to expect that with time, the ambitious and strategic thinking informal business owner would want to grow the business which leads to the need to formalise. The goal of this research is to provide a framework for comprehending what it takes to successfully formalise a previously informal business.

\subsection{The need for (importance of) formalisation}

From the point of view of policy makers and government, it can be argued that the transition of informal businesses to the formal sector is crucial because though informal businesses no doubt inject money into the economy and form part of the circular flow of income, these businesses cause distortions in measuring national accounts (Gërxhani, 2003) because of their ability to evade tax without trace making it virtually impossible to have an exact tax estimate when calculating GNP.

Although tax avoidance may provide an incentive to remain informal, another reason to formalise could be the desire to grow. Formalisation is vital for growth because banks for example would be expected to be more willing to finance a formal business than would be for the informal one. Opportunities for expansion into a viable business are therefore severely limited though not impossible when the business remains informal (Rolfe, Woodward, Ligthelm and Guimarães, 2010).

Barnard, Kritzinger, and Kruger (2011) declare that "SMMEs in South Africa play an increasingly important role in stimulating economic activity, growth and employment creation". This view is supported by Rootman and Kruger (2010) who point out that "SMMEs are important contributors to the economy as they provide employment opportunities and create economic wealth". Another advantage of SMMEs is their contribution to the country's gross domestic product (GDP). In the South African context, it is generally estimated that of all the formerly employed persons, SMMEs contribution is in the region of $50 \%$ whist contributing about $42 \%$ of the country's gross domestic product. Based on the aforesaid, it is important to reiterate in Michelle's (2011) words that "while the contribution of small businesses is often ignored, it shouldn't be so as SMMEs are set to lead economic recovery by helping to reduce unemployment levels across the globe, especially in developing countries".

The single most important aspect of the informal sector is that it is able to absorb the unemployed which the formal sector cannot do on its own. According to the United States Agency International Development [USAID] (2005), the informal economy significantly absorbs the unemployed in the USA. In South Africa, Blaauw (2005) indicates that the unemployed often turn to the informal sector as the last resort to finding a means of livelihood. It is estimated that there are between one (1) million and 2.3 million informal businesses in South Africa, which contribute between $7 \%$ and $12 \%$ to South Africa's GDP (Von Broembsen, 2007).

Whilst these reasons may make formalisation attractive to informal businesses, it is important to mention that like in all life endeavours, it will be preposterous for anyone to suggest that the transition will be all smooth sailing. Instead, one should expect challenges.

\section{Theoretical Framework}

Theories on the transition of firms from the informal business sector to the formal business sector appears informed by at least three different schools of thought namely: the dualist approach, the structuralist approach and the legalist approach. These theoretical approaches are briefly discussed.

Firstly, the dualist school promoted by the early work of the International Labour Organisation (ILO) in the 1970s conceives the informal sector as a set of separate marginal activities not linked directly to the formal sector. The dualist school views the informal sector as one that provides salary or safety net to the poor who are not competent to access employment in the formal sector. The dualistic school regards the persistence of informal activities to be consequence of a lack of job opportunities to absorb surplus labour due to a faster rate of economic growth (Menya, 2009). The dualist 
school of thought is somewhat contradictory to our view that the informal sector maximises a fast growing economy by creating jobs thus providing opportunities to the unemployed. This line of thinking flows from Neves (2010) who argues that the informal sector supports socio-economic growth.

Secondly, the structuralist school promoted by Castells, Portes and Moser (1989) and many others in the 1970s and 80 s view the informal sector as a set of subordinate of the formal sector. In this respect, Devey et al. (2006) view the informal sector as "a set of subordinated economic units who serve to reduce the input and labour costs of the large, formal enterprises". Growth in profitability in the formal sector is in part dependent on growth in the informal sector (Devey et al., 2006). Many authors share the view that structuralist subcontract the more labour-intensive parts of the production process to the informal firms in order to minimize labour costs. Janneke, Ana and Abdul (2011) argue that there is a positive relationship between employment in the formal and informal sectors but only in the most modern informal sector activities. The modern informal activity mentioned by Janneke et al. (2011) is the "entrepreneurial" side of the informal sector characterised by more hired workers per firm, more dynamic technology and substantial incomes.

While the above thoughts on the structuralist school have proven to be true in the case of India, these may not necessarily apply to South Africa because of contextual reasons. The argument of Janneke et al. (2011) apart from being in a different context is based on the assumption that two segments exist in the informal sector. The modern informal sector and the traditional informal sector- a "survivalist" free entry sector with little capital as opposed to South Africa where the subject is simply addressed as the informal sector without any segmentation.

Thirdly, the legalist school popularised by De Soto (1989), views the informal sector as comprising entrepreneurs who choose to carry on their activities in the shadow economy in order to avoid the challenges of formalisation such as cost of registration and long queues involved in the process of registration (Devey et al., 2006). This view is in line with the informal interviews with informal business owners in South Africa reported earlier.

Dzansi (2004) argues that SMMEs make more impact on society when they adopt strategic objectives of growth; market development; increased market share; and market positioning. Considering that formalising can enable informal businesses to grow, develop new markets, increase market share, and position themselves strategically in the market (Wickham, 2001; Dzansi, 2004), one wonders why so many informal businesses still exist in South Africa. But adopting any of these strategic postures will require formalising the business. To grow for instance will require an informal micro enterprise to raise capital and no investor or lender can be expected to inject money into an unregistered business. Thus from a strategic management or strategic entrepreneurship perspective, it makes sense for an informal business to formalize its operations.

\section{Conceptual Framework}

As captured in Figure 1 below, it is argued that long term or strategic motives drive informal business owner/manager's decision to formalize or not to. In other words, motives are the reasons for formalization which amongst others may include the vision and ambition of business owners to grow their business. Should the owner/manager decide to formalize, there are challenges to contend with (USAID, 2005).

Challenges consist of among others regulatory, bureaucracy and tax issues (USAID, 2005). Further, it is argued that the ability of an informal business to successfully negotiate these challenges will depend on certain background factors of owners and/ or managers. That is, in the end, only businesses whose owners/managers possess the right attributes to overcome the challenges will be able to transit (graduate) to a formal business. On the other hand, businesses whose owners or managers do not possess the right attributes may not be able to cope hence will remain informal.

Attributes that enable owners to overcome challenges may include entrepreneurial orientation, strategic orientation, level of education, networking abilities (Shane, 2005) just to mention a few. The 'graduated' businesses will all things being equal be able to derive benefits associated with formalization while society in general will also benefit for example from increased job creation, tax contributions and social responsibility contributions etc. When a business fails to 'graduate' hence remains informal, it will continue to provide owners with only survival income whilst depriving the state of taxes etc. 


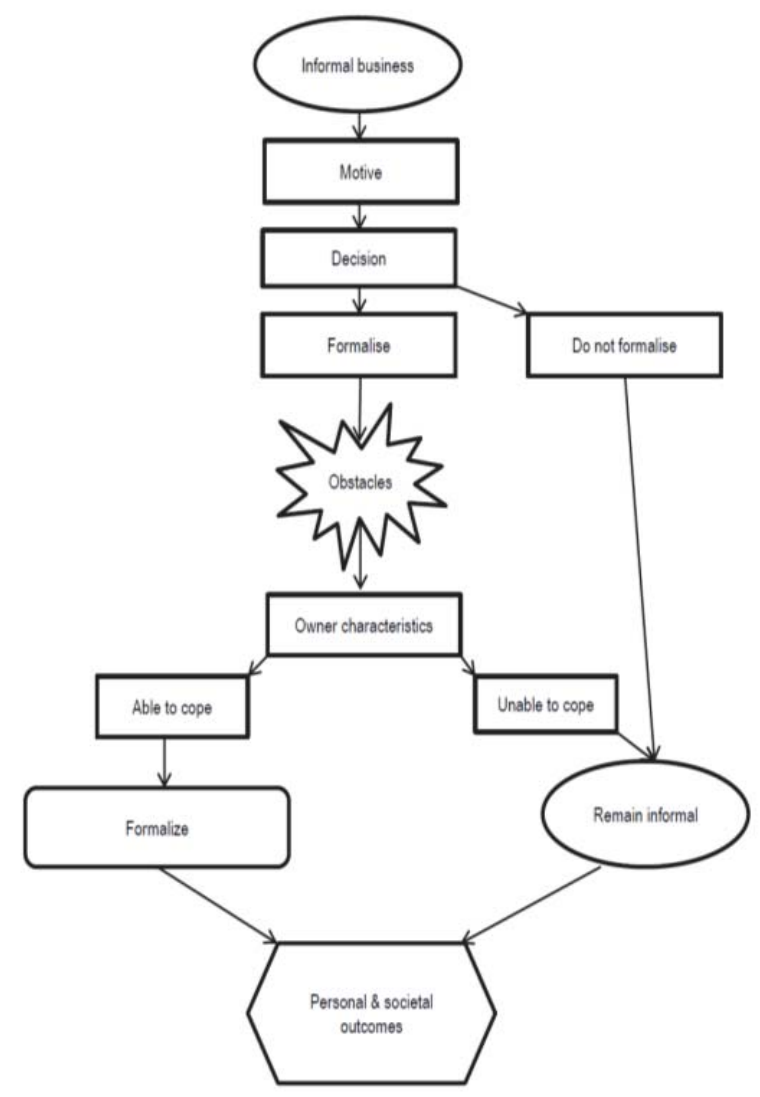

Figure 1:transition of informal to formal business

\section{Conclusion}

The position taken in this paper is that people's knowledge, views, understandings, interpretations, experiences, and interactions constitute meaningful properties of social reality. That is, social reality is best captured through the views, understandings, interpretations, and experiences of actors themselves. Thus, to understand the informal to formal business transition process, it is best to see it through the lenses of the 'graduated' owners.

The conceptual framework illustrated in in Figure 1 provides a tool for empirically investigating hence understanding what it takes informal businesses to 'graduate' to the formal sector in the South African context with possible application to other countries. As captured in Figure 1, the framework comprises of owner/ manager's long term or strategic motives that drive informal business owner/manager's decision to formalize or not to. The framework further shows that there are challenges to contend with when formalising an informal business. Further, it is argued that the ability of an informal business to successfully negotiate these challenges depend on certain background factors of owners and/ or attributes that may include entrepreneurial orientation, strategic orientation, level of education, networking abilities just to mention a few.

It is also postulated that in the end, all things being equal, 'graduated' businesses will be able to derive benefits associated with formalization while society in general will also benefit through increased job creation, tax contributions and social responsibility contributions etc. But when a business fails to 'graduate' hence remains informal, it will continue to provide owners with only survival income whilst depriving the state of taxes etc.

While there can be no one-size-fits-all framework to address a research problem, our framework provides a useful framework for understanding the difficult journey of formalising an informal business. In particular, academics, business support agencies, policy makers and students of the subject should find the framework useful. 


\section{References}

Barker, F. (2003). The South African Labour Market. $4^{\text {th }}$ Edition. Pretoria: Van Schaik.

Barnard, S. Kritzinger, B. and Kruger, J. (2011). Location decision strategies for improving SMME business performance. Acta Commercii, 11:111-128.

Blaauw, P.F. (2005). The Dynamics of the Informal Sector in South Africa. A Case Study of Day Labourers in Pretoria. Paper presented at the biennial conference of the Economic Society of South Africa. 7th - 9th September 2005, Durban, South Africa.

Devey, R., Skinner, C. and Valodia, I. (2006). The State of the Informal Economy. In: Buhlungu, S. et al. (Eds) State of the Nation: South Africa 2005-2006. [Online] (Available from http://www.hsrcpress.ac.za/. [Accessed 0205/2014].

De Soto, H. (1989). The Other Path: Invisible Revolution in the Third World. New York: Harper and Row.

Dzansi D.Y. and Pretorius M. 2009. The development and structural confirmation of an instrument for measuring the social responsibility of small and micro businesses in the African context. Journal of Social Responsibility, 5(4):450-463.

Dzansi, D.Y. (2004). Social responsibility of SMMEs in rural communities. A PhD thesis, University of Pretoria, South Africa.

Gërxhani K. (2004). The Informal Sector in Developed and Less Developed Countries: A Literature Survey. Public Choice, 120:267-30

Hart, K. (1973). Informal Income Opportunities and Urban Employment in Ghana. Journal of Modern African Studies. 2(1):61-89.

International Labour Organisation (ILO). (1972). Employment, Incomes and Equity: a Strategy for Increasing Productive Employment in Kenya, ILO: Geneva.

Mason, J. (2007). Qualitative Researching. 2nd Ed. London: Sage.

Michelle, S. (2011). Small businesses are set to lead economic recovery: SMMEs and economic recovery. Professional Accountant, Oct/Nov: $10-12$.

Organisation for Economic Co-operation and Development (OECD). (2005). Small business, job creation and growth: facts, obstacles and best practices. [Online]. Available from: http://www.oecd.org/industry/smesandentrepreneurship/2090740.pdf [Accessed 0205/2014].

Portes, A. and Haller, W. (2005). The informal economy. In Smelser, L.J. and Swedberg, R. (Eds). Handbook of Economic Sociology. 2nd Ed. 403-427. New Jersey: Princeton University.

Republic of South Africa. (1996). National Small Business Act. No. 102 of 1996. Pretoria: Government printer.

Republic of South Africa. (2004). National Small Business Amendment Act, No. 29 of 2004. Pretoria: Government printer.

Rolfe, R. Woodward, D. Ligthelm, A. and Guimarães, P. (2010). The viability of informal micro-enterprise in South Africa. A paper presented at the conference on -Entrepreneurship in Africa. Whitman School of Management, Syracuse University, Syracuse, New York.

Rootman, C. and Kruger, J. (2010). Adapting SMME business functions during economic turmoil. Acta Commercii, 10:107-119.

Shane, S. (2005). A general theory of entrepreneurship: the individual-opportunity nexus. Cheltenham: Edward Elger.

Statistics South Africa (STATSA). (2003). Labour Force Survey. Pretoria: Government printers.

United States Agency International Development (USAID). (2005). Barriers to Formalization. The case for reform and emerging best practice. [Online]. Available from http://www.oecd.org/dac/povertyreduction/38452590.pdf [accessed on 03/03/2014].

Von Broembsen, M. (2003). Poverty alleviation: beyond the National Small Business Strategy. [Online]. Available from: http://www. idasa.org.za. [Accessed 12/06/2013] 